\title{
Effects of season, lactation and plane of nutrition on the reproductive performance and associated plasma $L H$ and progesterone profiles in hormonally treated ewes
}

\author{
S. M. Rhind $\dagger$, J. J. Robinson, J. M. Chesworth* and M. Phillippo \\ Rowett Research Institute, Bucksburn, Aberdeen AB2 9SB, and *University of Aberdeen, \\ Department of Agriculture, 581 King Street, Aberdeen AB9 1UD, U.K.
}

\begin{abstract}
Summary. Two experiments were designed to determine the effects of duration of lactation and plane of nutrition on the reproductive performance of Finn $\times$ Dorset Horn ewes mated at a hormonally induced oestrus 9 weeks after lambing. In Exp. 1, ewes were mated on 4 December or 19 March and lactation was terminated at 35 or 15 days before mating or 7 or 35 days after mating. The fertility of ewes lactating at the time of mating was reduced, particularly in ewes mated in March. This was not attributable to differences between lactating and non-lactating ewes for the incidence of oestrus, ovulation rate, litter size or the pattern of $\mathrm{LH}$ production. Indirect evidence based on progesterone profiles and returns to service suggest that reproductive failure was due to failure of fertilization and to embryonic death.

In Exp. 2 ewes were mated on 1 July or 15 October. Lactation was terminated 15 days before or 7 days after mating and the ewes in each group were subjected to a high or low plane of nutrition. Lactation depressed fertility in ewes mated in July but not in those mated in October. While the fertility of non-lactating ewes was independent of nutritional treatment, lactating ewes on a low plane and mated in July had a higher lambing rate than those on a high plane of nutrition. Nutritional effects on fertility appeared to be mediated through changes in milk production and reproductive failures were attributed to failure of fertilization and embryonic death. Seasonal and treatment effects on the incidence of oestrus and on ovulation rates, litter sizes and LH production were small and of little importance.
\end{abstract}

\section{Introduction}

Studies in which Finnish Landrace $\times$ Dorset Horn ewes were kept under artificial daylength conditions and weaned after 1 month of lactation (Robinson, Fraser \& McHattie, 1975) showed that conception rates of about $90 \%$ and litter sizes greater than 2 could be obtained consistently in a breeding programme involving a 7-month interval between lambings. This interval was achieved by the synchronization of oestrus using intravaginal pessaries impregnated with progestagen. Subsequent studies (Fraser, Robinson, McHattie \& Gill, 1976) showed that a similar level of production could be obtained from ewes of this breed kept under natural daylength conditions, provided that each ewe was given a small dose (400 i.u.) of pregnant mares' serum gonadotrophin (PMSG) at the time of pessary withdrawal. Important features of these studies were the high plane of nutrition $(1.75 \times$ maintenance) of the ewes between weaning and remating and the termination of lactation before rebreeding. While weaning before the time of rebreeding eliminates any possibility of adverse effects of lactation on subsequent fertility, it imposes a degree of restriction on the intensive system of sheep production that may not always be acceptable in practice.

$\dagger$ Present address: Hill Farming Research Organisation, Bush Estate, Penicuik, Midlothian EH26 0PY, U.K. 
Fertility is generally depressed when ewes are mated during lactation, particularly during the anoestrous season (Cognie, Hernandez-Barreto \& Saumande, 1975; Dawe \& Fletcher, 1976) or are kept on a low plane of nutrition before mating, particularly when in poor condition (Coop, 1966). Some studies on the fertility of lactating ewes induced to breed during anoestrus have been made (Cognie et al., 1975) but little is known of the effects of time of weaning and plane of nutrition on the fertility of ewes bred more frequently than once a year. Shevah, Black \& Land (1975) attempted to breed non-lactating and lactating ewes within 35 days after parturition but obtained poor lambing rates. Their results may have been influenced by the fact that uterine regression was unlikely to have been complete at this time, particularly in lactating ewes (Choffardet, 1971; Honmode, 1977). In addition the effects of plane of nutrition on the fertility of lactating ewes were not assessed.

The present paper reports the results of two experiments on the effects of duration of lactation, season of breeding and nutritional status on some aspects of the reproductive performance and endocrine status of Finnish Landrace $\times$ Dorset Horn ewes mated at a hormonally-induced oestrus 9 weeks after lambing.

\section{Materials and Methods}

\section{Animals and management}

Both experiments involved F1 generation ewes that had previously been bred at intervals of 210 days. They were individually penned with their lambs and, although housed at all times, were subjected to daylength conditions natural at $57^{\circ} 10^{\prime} \mathrm{N} 2^{\circ} 04^{\prime} \mathrm{W}$. The ewes were randomly allocated to their treatments immediately after parturition. From 2 weeks of age the lambs had free access to a creep feed. Oestrus was synchronized with intravaginal pessaries impregnated with $30 \mathrm{mg}$ Cronolone (G. D. Searle Ltd) plus $400 \mathrm{mg}$ progesterone (Sigma Chemicals, St. Louis, Missouri, U.S.A.) dispersed in fine crystals throughout the pessary as described by Gordon (1971). Pessaries were inserted for 12 days from 53 (s.e. \pm 0.3 ) days post partum, and each ewe was given an intramuscular injection of 400 i.u. PMSG (Folligon, batch 1404: Intervet Ltd, Bar Hill, Cambridge, U.K.) in $2 \mathrm{ml}$ sterile saline $(9 \mathrm{~g} \mathrm{NaCl} / \mathrm{l})$ at pessary withdrawal. Two days later all ewes were hand mated to Suffolk rams. Each ewe was mated at approximately 24 and $36 \mathrm{~h}$ after the onset of oestrus. In Exp. 1 ewes were mated on 4 December (Flock D) or 19 March (Flock M) and in Exp. 2 on 1 July (Flock J) or 15 October (Flock O).

\section{Experiment 1}

The mean ( \pm s.e.m.) weights of the ewes in Flocks D and $\mathrm{M}$ immediately after parturition were $62 \pm 1.2$ and $69 \pm 1.2 \mathrm{~kg}$ respectively and the corresponding mean numbers of lambs reared by each ewe were $1.9 \pm 0.06$ and $2.0 \pm 0.06$

Treatments. Within each flock the animals were allocated to 1 of 4 weaning times. These corresponded to $30,50,70$ or 100 days after parturition and are designated $W 30, W 50, W 70$ and W 100 respectively. Thus lactation was terminated at 35 or 15 days before mating or 7 or 35 days after mating. During lactation the ewes were given ad libitum a complete diet. Their mean daily intakes of metabolizable energy (ME) were over $30 \mathrm{MJ}$ throughout lactation. At weaning the daily ME intake of the W30, W50 and W70 ewes was reduced to $14 \mathrm{MJ}$ and 1 month after mating to $7 \mathrm{MJ}$ whereas $\mathrm{W} 100$ ewes had their daily intake reduced directly to $7 \mathrm{MJ}$ at weaning. The changes in ewe liveweight provide an index of their nutritional status and are given in Textfig. 1 .

Mean lamb growth rates, which are an index of milk yield, were $270 \pm 6 \mathrm{~g}$ /day during the first 30 days of lactation when creep feed intakes were negligible and rose to $360 \pm 19 \mathrm{~g} /$ day after Day 70 of lactation when the mean daily ME intakes from the creep feed were $3.5 \pm 0.47 \mathrm{MJ} / \mathrm{lamb}$. 


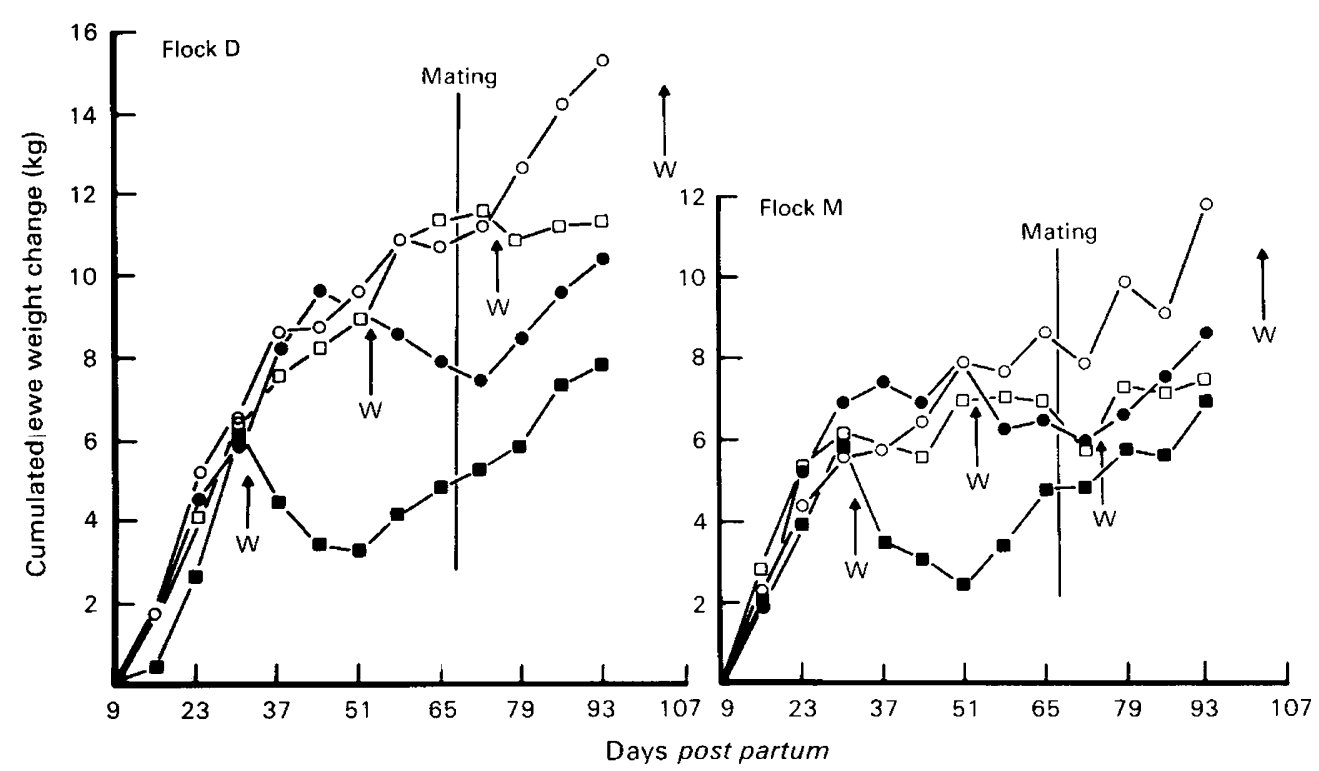

Text-fig. 1. Changes in mean weights of the ewes in Flock D (mated in December) and Flock M (mated in March) and weaned (W) after approximately $30(\mathbf{\square}), 50(\bigcirc), 70(\square)$ or $100(\mathrm{O})$ days of lactation.

\section{Experiment 2}

The mean ( \pm s.e.m.) weights of the ewes in Flocks $\mathbf{J}$ and $\mathrm{O}$ immediately after parturition were $66 \pm 1.5$ and $72 \pm 1.7 \mathrm{~kg}$ respectively and the corresponding mean numbers of lambs reared by each ewe were $2 \cdot 2 \pm 0 \cdot 10$ and $2 \cdot 0 \pm 0.08$.

Treatments. Within each flock the ewes were allocated to 1 of 4 treatments according to a 2 $\times 2$ factorial design comprising 2 weaning times and 2 planes of nutrition. The weaning times were 50 and 70 days after parturition, i.e. 15 days before and 7 days after mating. After free access for the first 50 days of lactation to a complete diet which resulted in a mean daily ME intake of about $25 \mathrm{MJ}$, the ewes within each weaning group were allocated to a high $(\mathrm{H})$ or low (L) plane of nutrition. For each plane of nutrition the nutrient intakes were estimated to maintain the same nutritional state in lactating and non-lactating ewes between 50 and 70 days after parturition and to sustain these in all ewes for the next 30 days. The treatment groups were designated W50H, W50L, W70H and W70L. During lactation the daily ME intakes were approximately 25 and $16 \mathrm{MJ}$ for the high and low planes of nutrition respectively. Corresponding values after weaning were 14 and $7 \mathrm{MJ}$. As in Exp. 1 the changes in ewe liveweight are given in Text-fig. 2 and provide an index of the nutritional status of the ewes.

The lamb weight gains in conjunction with the ME intakes as creep feed were used as an index of ewe milk yield and were $266 \pm 7 \mathrm{~g}$ and $0.9 \pm 0.06 \mathrm{MJ}$ of ME/day respectively in the first 50 days of lactation. Values in the period 50-70 days of lactation for Groups W70H and W70L were $370 \pm 21$ and $296 \pm 15 \mathrm{~g}(P<0.01)$ respectively for weight gain and $4.6 \pm 0.49$ and $5 \cdot 1 \pm 0 \cdot 35 \mathrm{MJ}$ for creep feed intake.

\section{Measurements}

The incidence of oestrus from 2 weeks post partum until pessary insertion was assessed by exposing the ewes to a vasectomized ram each day. The time of the onset of oestrus following 


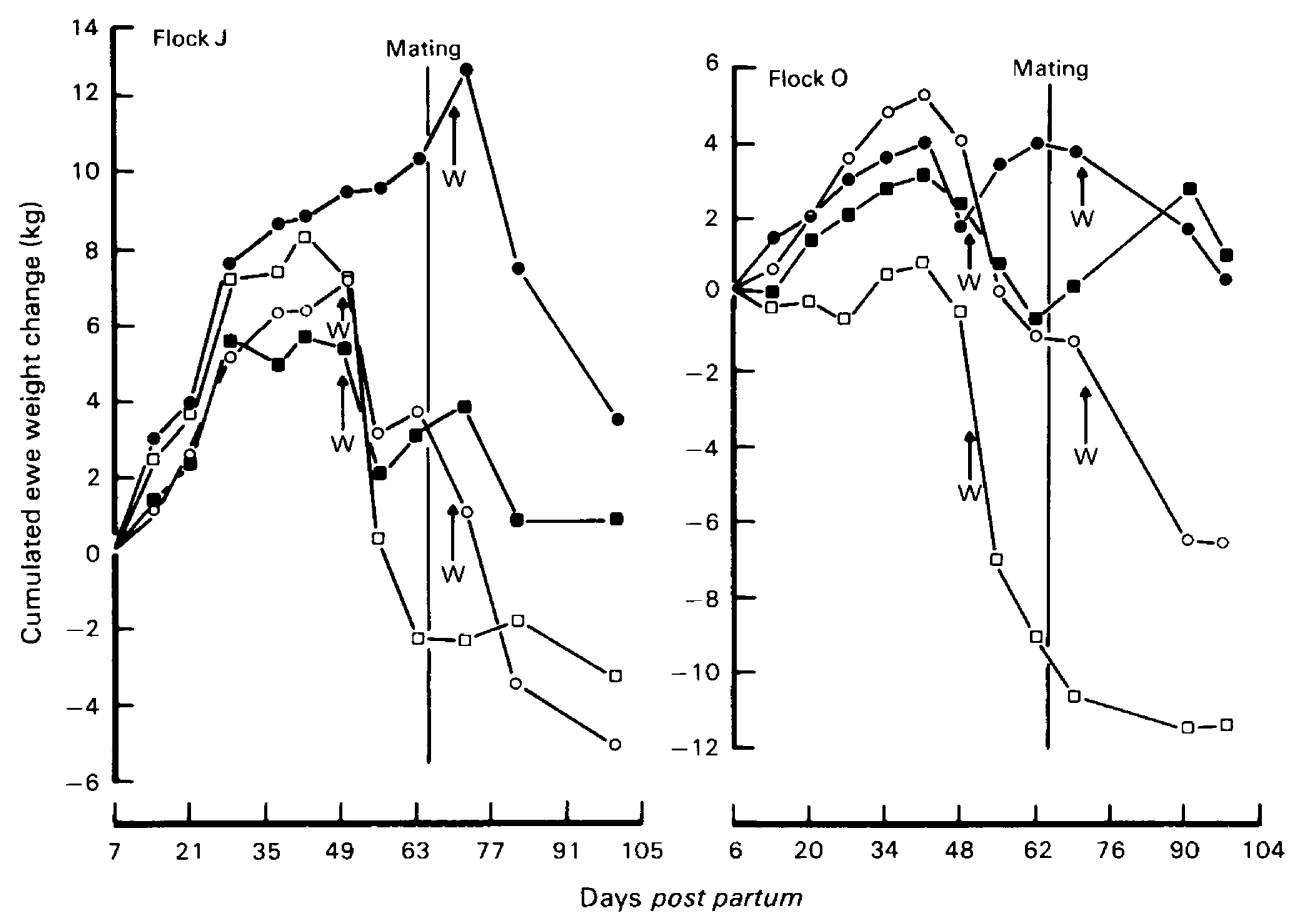

Text-fig. 2. Changes in mean weights of the ewes in Flock J (mated in July) and Flock O (mated in October) and subjected to different times of weaning (W) (50 or 70 days) and high or low plane of nutrition: W50L (口), W50H (ם), W 70L (O), W70H (๑).

hormone treatment was similarly determined with tests every $6 \mathrm{~h}$. Ovulation rates were determined by laparoscopy using the technique of Phillippo \& Rhind (1977).

From the time at which the first ewes were observed in oestrus until $27 \mathrm{~h}$ after the onset of oestrus, blood samples were collected from each ewe, by jugular venepuncture, every $3 \mathrm{~h}$. Plasma samples were assayed for LH by the radioimmunoassay method of Chesworth (1977). The standard was NIH-LH-S17.

Plasma progesterone concentrations were determined once or twice per week during the first 2 months after the induced oestrus to provide a measure of luteal activity and for pregnancy diagnosis. The radioimmunoassay technique was a modification of that of Henricks, Dickey \& Hill (1971). The antiserum (Y 29/6) was raised in sheep to 6 $\beta$-hydroxyprogesterone-hemisuccinyl-BSA and diluted to $1: 4000$ in PBS- $0 \cdot 1 \%$ gelatin. Cross-reactions were $8.8 \%$ with $5 \beta$ pregnane-3,20-dione, $11 \cdot 1 \%$ with deoxycorticosterone and $\leqslant 0.2 \%$ with other steroids. Average recovery of $\left[{ }^{3} \mathrm{H}\right]$ progesterone from plasma for each of 4 concentrations within the range $0.5-9 \cdot 5$ $\mathrm{ng} / \mathrm{ml}$ was $78 \pm 0.7 \%(n=12$ for each concentration) and intra- and inter-assay coefficients of variation were $12 \%(n=19)$ and $22 \%(n=42)$ respectively. The sensitivity of the assay was $0.04 \mathrm{ng} /$ tube.

\section{Statistical methods}

Most of the results were analysed by a 2-way classification analysis of variance in which the main effects of season and treatment and their interaction were examined. Data concerning ovulation rates and litter sizes were analysed by the Mann-Whitney U-test, a non-parametric test which involves ranking of the data (Siegel, 1956). 


\section{Results}

\section{Experiment 1}

Oestrous activity between parturition and pessary insertion. The proportion of ewes that showed oestrus (Table 1$)$ was greater in Flock $M$ than $D(P<0.001)$ and for ewes of Group W30 than for Groups W50/70/100 combined $(P<0.05)$. The mean interval from parturition to first oestrus was shorter $(P<0.05)$ in Flock $M$.

Table 1. Incidence and time of occurrence of overt oestrus between lambing and pessary insertion in relation to month of mating and time of weaning (Exp. 1)

\begin{tabular}{|c|c|c|c|c|}
\hline \multirow[b]{3}{*}{ Group } & \multicolumn{4}{|c|}{ Month of mating } \\
\hline & \multicolumn{2}{|c|}{ December (Flock D) } & \multicolumn{2}{|c|}{ March (Flock M) } \\
\hline & W30 & W50/70/100 & W30 & W $50 / 70 / 100$ \\
\hline No. of ewes/treatment & 10 & 32 & 12 & 35 \\
\hline No. of ewes showing overt oestrus & 1 & 1 & 7 & 12 \\
\hline $\begin{array}{l}\text { Interval (days) from lambing to overt } \\
\text { oestrus (mean and range) }\end{array}$ & $46 \cdot 0$ & $45 \cdot 0$ & $42 \cdot 0(35-41)$ & $48 \cdot 3(45-54)$ \\
\hline
\end{tabular}

Oestrous activity and ovulation rates after pessary withdrawal. One ewe (Group W70, Flock M) failed to show oestrus after pessary withdrawal. While there were no significant differences between lactating and non-lactating ewes in the interval between pessary removal and oestrus onset (Table 2) the interval was shorter by about $8 \mathrm{~h}$ for Flock $M$ ewes. Overall mean ovulation rates $( \pm$ s.e.m.) were $2.9 \pm 0.15$ (Flock D) and $3.1 \pm 0.16$ (Flock M) and the range was similar for all groups.

Table 2. Oestrous activity and ovulation rates of ewes after pessary withdrawal in relation to month of mating and time of weaning (Exp. 1)

\begin{tabular}{|c|c|c|c|c|c|c|c|c|c|}
\hline & \multicolumn{6}{|c|}{ Month of mating and group } & \multirow[b]{3}{*}{ r.s.d.* } & \multirow{2}{*}{\multicolumn{2}{|c|}{$\begin{array}{l}\text { Significance of } \\
\text { differences }\end{array}$}} \\
\hline & \multicolumn{3}{|c|}{ December (Flock D) } & \multicolumn{3}{|c|}{ March (Flock M) } & & & \\
\hline & W30 & W50 & $W 70 / 100$ & W30 & W50 & $W 70 / 100$ & & Treatments & Season \\
\hline No. of ewes/treatment & 10 & 10 & 22 & 12 & 12 & 23 & \multirow{7}{*}{$5 \cdot 66$} & \multirow{4}{*}{ N.S. } & \multirow{4}{*}{$P<0.001$} \\
\hline $\begin{array}{l}\text { No. of ewes showing } \\
\text { oestrus }\end{array}$ & 10 & 10 & 22 & 12 & 12 & 22 & & & \\
\hline $\begin{array}{l}\text { Mean interval from } \\
\text { pessary removal to } \\
\text { observed oestrus }(h)\end{array}$ & $36 \cdot 1$ & $40 \cdot 1$ & $39 \cdot 5$ & $32 \cdot 0$ & $30 \cdot 0$ & $30 \cdot 8$ & & & \\
\hline $\begin{array}{l}\text { No. of ewes examined } \\
\text { by laparoscopy }\end{array}$ & 6 & 6 & 8 & 5 & 6 & 11 & & & \\
\hline \multicolumn{7}{|l|}{ No. of CL } & & \multirow{3}{*}{ N.S. } & \multirow{3}{*}{ N.S. } \\
\hline Mean & $2 \cdot 7$ & $3 \cdot 2$ & $2 \cdot 9$ & $2 \cdot 6$ & $3 \cdot 2$ & $3 \cdot 3$ & & & \\
\hline Range & $1-4$ & $3-4$ & $2-4$ & $2-3$ & $2-5$ & $2-4$ & & & \\
\hline
\end{tabular}

* Residual standard deviation.

Lambing rates and litter sizes. At least $80 \%$ of ewes which had their lambs removed before mating lambed to the induced oestrus (Table 3 ) at each of the 2 times of year. In contrast, lactating ewes had a significantly lower lambing rate $(P<0.001)$ and this was most marked for those mated in March when just over one-third lambed to the induced oestrus. Although the mean litter size for the ewes that lambed to the induced oestrus was smaller for Flock M (2.2 \pm $0 \cdot 15)$ than Flock D $(2.6 \pm 0 \cdot 16)$ ewes, this seasonal difference was not significant. 
Table 3. Ewes lambing to the induced and repeat oestrus, oestrous activity after mating and mean litter sizes of ewes lambing to the induced oestrus in relation to month of mating and time of weaning (Exp. 1)

\begin{tabular}{|c|c|c|c|c|c|c|c|c|}
\hline & \multicolumn{8}{|c|}{ Month of mating and group } \\
\hline & \multicolumn{4}{|c|}{ December (Flock D) } & \multicolumn{4}{|c|}{ March (Flock M) } \\
\hline & W30 & W50 & W70 & W 100 & W30 & W50 & W 70 & W 100 \\
\hline No. of ewes/treatment & 10 & 10 & 10 & 12 & 12 & 12 & $11^{*}$ & 12 \\
\hline No. lambing to induced oestrus & 10 & 8 & 7 & 7 & 11 & 10 & 4 & 4 \\
\hline No. lambing to repeat oestrus & - & 1 & 2 & 2 & 0 & 0 & 3 & 3 \\
\hline No showing 2 nd repeat oestrus & - & 0 & 0 & 2 & 1 & 1 & 1 & 2 \\
\hline $\begin{array}{l}\text { No. failing to return to oestrus } \\
\text { at } 14-21 \text { days and failing to } \\
\text { lamb }\end{array}$ & - & 1 & 1 & 1 & 0 & 1 & $1 \dagger$ & $2+$ \\
\hline \multicolumn{9}{|l|}{ No. of lambs born/ewe lambing } \\
\hline Mean & $2 \cdot 6$ & $2 \cdot 8$ & $1 \cdot 7$ & $3 \cdot 3$ & $2 \cdot 3$ & $2 \cdot 2$ & $2 \cdot 0$ & $2 \cdot 5$ \\
\hline Range & $2-3$ & $1-4$ & $1-3$ & $2-5$ & $1-4$ & $1-3$ & $1-3$ & $2-3$ \\
\hline $\begin{array}{l}\text { Mean no. of lambs born/ewe put to } \\
\text { ram }\end{array}$ & $2 \cdot 6$ & $2 \cdot 2$ & $1 \cdot 2$ & $1 \cdot 9$ & $2 \cdot 1$ & $1 \cdot 8$ & 0.7 & $0 \cdot 8$ \\
\hline
\end{tabular}

* One ewe failed to show oestrus after pessary withdrawal.

† One ewe in each group (not in table) had an abnormally long interval between periods of oestrus.

Of the ewes that failed to lamb to the induced oestrus, 7 (26\%) failed to show oestrus 14-21 days after mating. The progesterone levels (Text-fig. 3) in 5 of these ewes (Category A) were elevated for at least 20 days and in some ewes for more than 60 days after mating. Another ewe (Category B) initially had elevated progesterone concentrations but these declined to $<1 \mathrm{ng} / \mathrm{ml}$ at Day 18 and then rose, suggesting a 'silent heat'. The remaining ewe (Category $C$ ) had progesterone concentrations of $1.0-1.5 \mathrm{ng} / \mathrm{ml}$ during the first few days after mating and $<1$ $\mathrm{ng} / \mathrm{ml}$ at Day 10 after mating. Progesterone levels then rose to normal values for several days and declined again to $<1 \mathrm{ng} / \mathrm{ml}$ at Day 27.

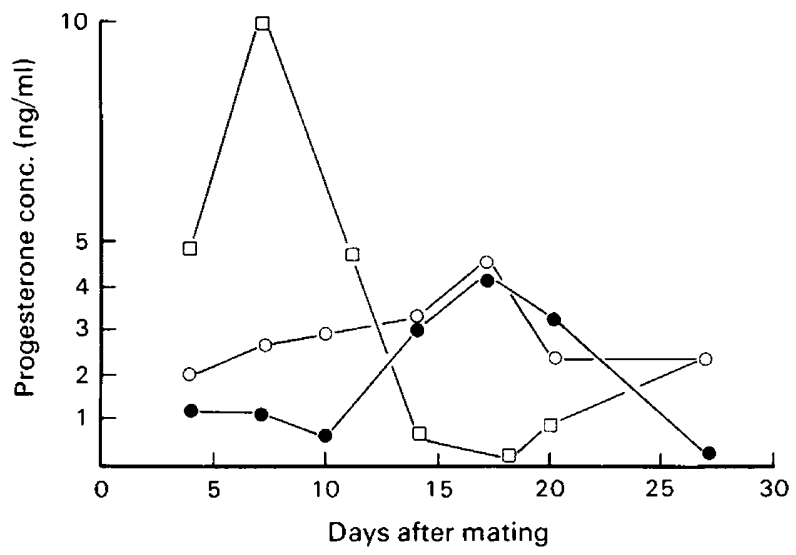

Text-fig. 3. Examples of the patterns of progesterone concentrations in three categories of ewes that failed to show a repeat oestrus and did not lamb: 0 , Category $A ; \square$, Category $B$;, Category C.

Pattern of LH production. Basal plasma $\mathrm{LH}$ concentrations were generally $<2 \mathrm{ng} / \mathrm{ml}$ in ewes of both flocks.

The highest concentration of $\mathrm{LH}$ recorded in the plasma samples collected during oestrus was arbitrarily designated as the preovulatory peak height. The precise areas under the peaks 
were not assessed but an indication of their relative sizes was obtained by summation of the values recorded during the period when plasma LH levels were elevated. Of the variables measured, only the mean interval from oestrus onset to the start of the LH peak differed $(P<$ 0.05 ) between ewes which conceived to the induced oestrus and those that did not, the interval being greater for ewes which failed to lamb to the induced oestrus ( 8.6 compared with $5 \cdot 1 \mathrm{~h})$. As the difference was small and probably of no biological significance, all the data were pooled for further analysis (see Table 4). No significant differences were found between weaning times for any of the variables investigated, but there was a small seasonal difference in the timing of the LH peak.

Table 4. Mean times to onset of LH peaks, and mean peak heights and 'areas' for ewes in relation to month of mating and time of weaning (Exp. 1)

\begin{tabular}{|c|c|c|c|c|c|c|c|c|}
\hline & \multicolumn{6}{|c|}{ Month of mating and group } & \multirow[b]{3}{*}{ r.s.d.* } & \multirow{3}{*}{$\begin{array}{l}\text { Significance } \\
\text { of seasonal } \\
\text { differences }\end{array}$} \\
\hline & \multicolumn{3}{|c|}{ December (Flock D) } & \multicolumn{3}{|c|}{ March (Flock M) } & & \\
\hline & W30 & W50 & $\mathrm{W} 70 / 100$ & W30 & W50 & $W 70 / 100$ & & \\
\hline $\begin{array}{l}\text { Interval from pessary } \\
\text { removal to start of } \mathrm{LH} \\
\text { peak (h) }\end{array}$ & $42 \cdot 0$ & 42.9 & $45 \cdot 1$ & $40 \cdot 5$ & $36 \cdot 8$ & $39 \cdot 7$ & $7 \cdot 42$ & $P<0.01$ \\
\hline $\begin{array}{l}\text { Interval from onset of } \\
\text { oestrus to start of LH } \\
\text { peak (h) }\end{array}$ & $6 \cdot 0$ & $2 \cdot 8$ & $5 \cdot 7$ & $8 \cdot 5$ & $6 \cdot 8$ & $8 \cdot 8$ & $5 \cdot 00$ & $P<0.01$ \\
\hline \multicolumn{9}{|l|}{ Peak height $(\mathrm{ng} / \mathrm{ml})$} \\
\hline Mean & $90 \cdot 0$ & 97.4 & $84 \cdot 6$ & 73.9 & 88.7 & $94 \cdot 1$ & $42 \cdot 40$ & N.S. \\
\hline Range & $25-141$ & $40-154$ & $18-174$ & $38-121$ & $34-143$ & $15-276$ & & \\
\hline Mean peak 'area' (ng/ml) & $181 \cdot 9$ & $193 \cdot 4$ & $173 \cdot 5$ & $145 \cdot 0$ & $187 \cdot 5$ & $173 \cdot 4$ & $66 \cdot 66$ & N.S. \\
\hline
\end{tabular}

* Residual standard deviation.

\section{Experiment 2}

Oestrous activity between parturition and pessary insertion. Oestrus was not recorded in any Flock $\mathrm{J}$ ewes before pessary insertion but $26 \%$ ( 11 ewes) of Flock $\mathrm{O}$ showed oestrus at a mean interval of $42.9 \pm 1.30$ (range: $35-48$ ) days after lambing.

Oestrous activity and ovulation rate following pessary withdrawal. One ewe in Flock $\mathrm{J}$ was discarded because the pessary could not be removed. Another 6 (14.6\%) ewes in Flock J and 1 ewe in Flock $\mathrm{O}$ failed to show an overt oestrus within $70 \mathrm{~h}$ of pessary withdrawal (see Table 5).

Table 5. Oestrous activity and ovulation rates of ewes after pessary withdrawal in relation to month of mating, time of weaning and level of feeding (Exp. 2)

\begin{tabular}{|c|c|c|c|c|c|c|c|c|}
\hline & \multicolumn{8}{|c|}{ Month of mating and group } \\
\hline & \multicolumn{4}{|c|}{ July (Flock J) } & \multicolumn{4}{|c|}{ October (Flock O) } \\
\hline & $\mathrm{W} 50 \mathrm{H}$ & W50L & $\mathrm{W} 70 \mathrm{H}$ & W70L & W50H & W50L & W70H & W70L \\
\hline No. of ewes/treatment & 8 & 10 & 8 & 15 & 8 & 10 & 8 & 16 \\
\hline No. showing oestrus & 6 & 10 & 6 & 13 & 8 & 9 & 8 & 16 \\
\hline $\begin{array}{l}\text { Mean interval from pessary } \\
\text { removal to first oestrus (h)* }\end{array}$ & $30 \cdot 3$ & $36 \cdot 6$ & $33 \cdot 9$ & $33 \cdot 2$ & $31 \cdot 6$ & $33 \cdot 2$ & $41 \cdot 4$ & $35 \cdot 0$ \\
\hline $\begin{array}{l}\text { No. of ewes examined by } \\
\text { laparoscopy }\end{array}$ & 2 & 5 & 1 & 6 & 5 & 5 & 5 & 6 \\
\hline \multicolumn{9}{|l|}{ No. of $C L$} \\
\hline Mean & $2 \cdot 0$ & $2 \cdot 4$ & $2 \cdot 0$ & $2 \cdot 7$ & $3 \cdot 2$ & $2 \cdot 4$ & $2 \cdot 4$ & $3 \cdot 0$ \\
\hline Range & $1-2$ & $2-3$ & - & $2-3$ & $2-4$ & $2-3$ & $1-4$ & $2-5$ \\
\hline
\end{tabular}

* The residual standard deviation was 0.56 . 
For those ewes that exhibited oestrus the mean interval from pessary withdrawal to onset of oestrus was not significantly affected by time of weaning, plane of nutrition or season. The same was true for ovulation rate (Table 5) although the overall mean value was slightly lower for Flock $J$ ewes $(2.3 \pm 0.14)$ than for Flock $O$ ewes $(2.8 \pm 0.21)$. The variation in ovulation rates did not differ significantly with treatment.

Lambing rates and litter sizes. In Flock $J$ the lambing rates of ewes which had had their lactations terminated before the time of mating were higher than those of ewes lactating at the time of mating and this was true for both nutritional treatments (see Table 6). In contrast, there was no evidence of such an effect for ewes in Flock $O$ in which conception rates were higher $(P<$ 0.01 ). For the ewes lambing to the induced oestrus litter size was not significantly affected by time of weaning or plane of nutrition but was slightly lower for those mated in July $(2 \cdot 2 \pm 0 \cdot 12)$ than in October $(2 \cdot 4 \pm 0 \cdot 17)$.

Table 6. Ewes lambing to the induced and repeat oestrus, oestrous activity after mating and mean litter sizes of ewes lambing to the induced oestrus, in relation to month of mating, time of weaning and level of feeding (Exp. 2)

\begin{tabular}{|c|c|c|c|c|c|c|c|c|}
\hline & \multicolumn{8}{|c|}{ Month of mating and group } \\
\hline & \multicolumn{4}{|c|}{ July (Flock J) } & \multicolumn{4}{|c|}{ October (Flock O) } \\
\hline & W50H & W50L & $\mathrm{W} 70 \mathrm{H}$ & W 70L & W50H & W50L & $\mathrm{W} 70 \mathrm{H}$ & W70L \\
\hline No. of ewes/treatment & 8 & 10 & 8 & 15 & 8 & 10 & 8 & 16 \\
\hline $\begin{array}{l}\text { No. failing to show overt } \\
\text { oestrus }\end{array}$ & 2 & 0 & 2 & 2 & 0 & 1 & 0 & 0 \\
\hline No. lambing to induced oestrus & 3 & 7 & 1 & 7 & 5 & 8 & 6 & 13 \\
\hline No. lambing to repeat oestrus & 0 & 1 & 3 & 3 & 0 & 0 & 2 & 1 \\
\hline $\begin{array}{l}\text { No. showing a } 2 \text { nd repeat } \\
\text { oestrus }\end{array}$ & 1 & 1 & 0 & 1 & 2 & 0 & 0 & 1 \\
\hline $\begin{array}{l}\text { No. failing to return to oestrus } \\
14-21 \text { days and failing to } \\
\text { lamb }\end{array}$ & 2 & 1 & 2 & 2 & 1 & 1 & 0 & 1 \\
\hline \multicolumn{9}{|l|}{ No. of lambs born/ewe lambing } \\
\hline Mean & $2 \cdot 3$ & $2 \cdot 0$ & $1 \cdot 0$ & $2 \cdot 4$ & $2 \cdot 0$ & $2 \cdot 0$ & $2 \cdot 7$ & $2 \cdot 7$ \\
\hline Range & $2-3$ & - & - & $2-3$ & $1-3$ & $1-3$ & $2-4$ & $2-4$ \\
\hline $\begin{array}{l}\text { Mean no. of lambs born/ewe } \\
\text { put to ram }\end{array}$ & 0.9 & 1.4 & $0 \cdot 1$ & $1 \cdot 1$ & $1 \cdot 3$ & $1 \cdot 6$ & $2 \cdot 0$ & $2 \cdot 2$ \\
\hline
\end{tabular}

Table 7. Mean times to onset of LH peaks, and mean peak heights and 'areas' for ewes in relation to month of mating, time of weaning and level of feeding (Exp. 2)

\begin{tabular}{|c|c|c|c|c|c|c|c|c|c|c|}
\hline & \multicolumn{8}{|c|}{ Month of flock and group } & \multirow[b]{3}{*}{ r.s.d.* } & \multirow{3}{*}{$\begin{array}{l}\text { Significance } \\
\text { of seasonal } \\
\text { differences }\end{array}$} \\
\hline & \multicolumn{4}{|c|}{ July (Flock J) } & \multicolumn{4}{|c|}{ October (Flock O) } & & \\
\hline & W50H & W50L & $\mathrm{W} 70 \mathrm{H}$ & W70L & W5OH & W50L & W70H & W70L & & \\
\hline No. of ewes/treatment & 8 & 10 & 6 & 14 & 8 & 9 & 8 & 16 & & \\
\hline $\begin{array}{l}\text { Interval from pessary } \\
\text { removal to start of } \\
\text { LH peak (h) }\end{array}$ & $35 \cdot 3$ & $41 \cdot 1$ & 39.5 & $45 \cdot 5$ & $40 \cdot 5$ & $39 \cdot 3$ & $49 \cdot 1$ & $45 \cdot 2$ & $10 \cdot 5$ & N.S. \\
\hline $\begin{array}{l}\text { Interval from oestrus } \\
\text { onset to start of } \\
\text { LH peak (h) }\end{array}$ & $5 \cdot 2$ & $4 \cdot 5$ & $5 \cdot 6$ & 7.6 & 8.9 & $6 \cdot 2$ & $7 \cdot 7$ & $10 \cdot 2$ & $5 \cdot 0$ & $P<0.05$ \\
\hline \multicolumn{11}{|l|}{ Peak height (ng/ml) } \\
\hline Mean & $72 \cdot 0$ & 71.7 & $48 \cdot 3$ & $60 \cdot 2$ & $80 \cdot 5$ & $56 \cdot 1$ & $57 \cdot 1$ & $70 \cdot 0$ & $28 \cdot 4$ & N.S. \\
\hline Range & $45-128$ & $50-96$ & $37-70$ & $13-118$ & $42-143$ & $12-125$ & $32-92$ & $18-123$ & & \\
\hline Mean peak area $(\mathrm{ng} / \mathrm{ml})$ & $138 \cdot 1$ & $130 \cdot 9$ & $97 \cdot 3$ & 111.4 & $144 \cdot 3$ & $116 \cdot 7$ & $108 \cdot 5$ & $135 \cdot 6$ & 43.9 & N.S. \\
\hline
\end{tabular}

\footnotetext{
* Residual standard deviation.
} 
Of the ewes that were mated at the induced oestrus and failed to lamb, $10(38 \cdot 5 \%)$ also failed to show an overt oestrus between 14 and 21 days after mating. Examination of the progesterone profiles of these animals showed that in 9 delayed luteal regression indicative of embryonic death had occurred while the remaining ewe had an unusually short luteal phase and an early return to basal plasma progesterone concentrations $(<1.0 \mathrm{ng} / \mathrm{ml})$.

Pattern of $L H$ production. The patterns of $\mathrm{LH}$ production in ewes which lambed to the induced oestrus and in those which did not were not significantly different. The data for the two categories were therefore pooled. Three of the ewes in Flock J which failed to show oestrus after hormonal treatment had LH surges which did not differ significantly from those of other ewes. These data were therefore included in the statistical analysis and the results are given in Table 7. The only significant effect was that of season on the interval from onset of oestrus to the start of the $\mathrm{LH}$ surge, the overall mean values being 5.9 and $8.6 \mathrm{~h}(P<0.05)$ for ewes mated in July and October respectively.

\section{Discussion}

The results of Exp. 1 show that even in the well nourished Finn $\times$ Dorset Horn ewe spontaneous oestrus tends to be inhibited by lactation and that the size of the effect is dependent on the season. Despite this natural inhibition, oestrus was readily induced by hormone treatment but fertility was depressed by lactation and this was particularly true for ewes mated in March. These effects on fertility were not due to differences in ovulation rates between lactating and nonlactating ewes or between those mated in December and those in March.

There are many reports which suggest that the reduced fertility of ewes mated at an induced oestrus during lactation or outwith the breeding season may be due to failure of fertilization because of abnormal timing of LH release or onset of oestrus (Cumming et al., 1970; Mauer et al., 1972; Lintin, Lamming \& Butt, 1973; Shevah, Black, Carr \& Land, 1974). There was no evidence of such abnormalities in the present study. Furthermore, contrary to the findings of Pelletier \& Thimonier (1973), Lewis, Bolt \& Inskeep (1974) and Cognie \& Pelletier (1976), the mean size of the LH surges was similar in non-lactating and lactating ewes, being consistent in both groups with the levels reported by others for non-lactating ewes (Geschwind \& Dewey, 1968; Scaramuzzi, Caldwell \& Moor, 1970; Kann, 1971). While there was considerable variation in the interval between onset of oestrus and the start of the LH peak, both within and between seasons, this period was not correlated with fertility.

Cognie \& Pelletier (1976) showed that in lactating ewes, a proportion of eggs are shed abnormally late in relation to the LH surge and may not be fertilized. The timing of ovulations was not investigated in the present work but in view of the fact that differences in lamb production between lactating and non-lactating ewes arose from differences in the incidence of barrenness and not from differences in litter size, it seems unlikely that our results were influenced by this phenomenon. In contrast, the results suggest that lactation interferes primarily with pregnancy establishment before implantation. This may be deduced by comparing the lambing rates of ewes of Groups W70 and W100; delaying weaning until after implantation (Group W100) resulted in little additional barrenness. It would appear that most wastage of eggs or embryos occurred during the first 12 days of pregnancy when the ewes were either still lactating (Group W100) or when influenced by possible residual effects of lactation (Group W70). The fact that most ewes which failed to lamb to the induced oestrus returned to the ram 14-21 days later is also indicative of complete failure of fertilization or early embryonic death, i.e. before Day 12 (Moor \& Rowson, 1964).

The observation, for 5 ewes which failed to lamb, of a prolonged elevation of plasma progesterone in early pregnancy suggests that embryo death also occurred after Day 12, because it seems unlikely that the elevated progesterone levels could result from the pessary and PMSG 
treatment or from the presence of progesterone residues in the vagina after pessary withdrawal. Combining data for early and late embryo loss showed that the total incidence was greatest in ewes which were lactating at the time of mating. This may be a function of abnormal ova or embryos in the lactating animals (Cognie et al., 1975) but it is also possible that luteal regression preceded embryonic death and was the cause of it. The occurrence of premature luteal regression in one ewe at about 7-10 days after mating supports this view. Short oestrous cycles have been recorded previously in lactating Finn $\times$ Dorset ewes (Land, 1971) and in hormonally treated non-lactating ewes of the same breed (J. J. Robinson, unpublished observations). They may be due to failure of the normal luteotrophic mechanisms or to abnormally early luteolytic activity.

The results of Exp. 2 illustrate the difficulties in controlling milk production and body tissue mobilization by altering only the plane of nutrition. The data suggest that the effects of nutrition on fertility were mediated through changes in milk production. For example, the higher conception rate for the ewes on a low (Group W70L) compared with a high (Group W70H) plane of nutrition was associated with a lamb growth rate which was $20 \%$ lower. As there was no effect of the plane of nutrition of the ewes on the intake of creep feed by the lambs, this reduction in lamb growth rate must have been associated with a reduction in daily milk yield. The evidence of similar differences in milk production within Flock $O$ which were not associated with differences in fertility requires further validation but may suggest a season $\times$ milk yield interaction on fertility.

The results of this experiment are consistent with the suggestion made above that part of the reduction in fertility of ewes at some times of year is the result of early embryonic death.

We thank Mr C. Fraser and Mr I. McHattie for technical assistance; Mr R. M. J. Crofts for the statistical analyses of the data; $\mathrm{Mr} \mathrm{G}$. Henderson for the $\mathrm{LH}$ determinations; and the National Institutes of Health, Bethesda, Maryland, for the LH. S.M.R. was in receipt of an Agricultural Research Council scholarship during the course of this work.

\section{References}

Chesworth, J.M. (1977) Radioimmunoassay of ovine luteinizing hormone and ovine prolactin using polymerised second antisera. Analyt. Biochem. 80, 3150.

Choffardet, R. (1971) L'anoestrus de lactation pendant l'anoestrus saisonnier chez la Brebis. Diplome de fin d'Etudes, E.N.S.A. Nancy. Cited by Cognie et al. (1975).

Cognie, Y. \& Pelletier, J. (1976) Preovulatory LH release and ovulation in dry and in lactating ewes after progestagen and PMSG treatment during seasonal anoestrum. Annls Biol. anim. Biochim. Biophys. 16, $529-536$.

Cognie, Y., Hernandez-Barreto, M. \& Saumande, J. (1975) Low fertility in nursing ewes during the nonbreeding season. Annls Biol. anim. Biochim. Biophys. 15, 329-343.

Coop, I.E. (1966) Effect of flushing on reproductive performance of ewes. J. agric. Sci., Camb. 67, 305323.

Cumming, I.A., Blockey, M.A. de B., Brown, J.M., Catt, K.J., Goding, J.R. \& Kaltenbach, C.C. (1970) The release of luteinizing hormone in ewes following the withdrawal of intravaginal sponges containing progestagen. Proc. Aust. Soc. Anim. Prod. 8, 383-387.
Dawe, S.T. \& Fletcher, I.C. (1976) The effect of post lambing interval on fertilization in lactating ewes treated with progestagen impregnated sponges and gonadotrophin. Proc. Aust. Soc. Anim. Prod. 11, $137-140$.

Fraser, C., Robinson, J.J., McHattie, I. \& Gill, J.C. (1976) Field studies on the reproductive performance of Finnish Landrace $\times$ Dorset Horn ewes. Proc. $\mathrm{Br}$. Soc. Anim. Prod. 5, 162-163.

Geschwind, I.I. \& Dewey, R. (1968) Dynamics of luteinizing hormone $(\mathrm{LH})$ secretion in the cycling ewe: a radioimmunoassay study. Proc. Soc. exp. Biol. Med. 129, 451-455.

Gordon, I. (1971) Induction of early breeding in sheep by standard and modified progestagen-PMSG treatments. J. agric. Sci., Camb. 76, 337-341.

Henricks, D.M., Dickey, J.F. \& Hill, J.R. (1971) Plasma estrogen and progesterone levels in cows prior to and during estrus. Endocrinology 89, 1350-1355.

Honmode, D. (1977) Post partum changes in the uterus of ewes. Anim. Breed Abstr. 45, 384.

Kann, G. (1971) Variations des concentrations plasmatique de l'hormone luteinisante et de la prolactine au cours du cycle oestrien de la Brebis. C. r. hebd. Séanc. Acad. Sci., Paris D 272, 2934-2937. 
Land, R.B. (1971) The incidence of oestrus during lactation in Finnish Landrace, Dorset Horn and Finn-Dorset sheep. J. Reprod. Fert. 24, 345-352.

Lewis, P.E., Bolt, D.J. \& Inskeep, E.K. (1974) Pattern of luteinizing hormone release in progestin treated ewes. J. Anim. Sci. 38, 1204-1209.

Lintin, K., Lamming, G.E. \& Butt, W.R. (1973) The effects of progestagens and pregnant mare's serum gonadotrophin on peripheral plasma luteinizing hormone levels in the Clun Forest ewes. J. Reprod. Fert. 35, 607-609.

Mauer, R.E., Revenal, P., Johnson, E.S., Moyer, R.H., Hirata, A. \& White, W.F. (1972) Levels of luteinizing hormone in sera of ewes near the time of estrus as determined by radioimmunoassay. J. Anim. Sci. $34,88-92$.

Moor, R.M. \& Rowson, L.E.A. (1964) Influence of the embryo and uterus on luteal function in the sheep. Nature, Lond. 201, 522-523.

Pelletier, J. \& Thimonier, J. (1973) Comparison of induced preovulatory luteinizing hormone discharge in lactating and dry sheep during seasonal anoestrus. J. Reprod. Fert. 33, 311-313.
Phillippo, M. \& Rhind, S.M. (1977) A new laparoscopic technique for the diagnosis of pregnancy and the estimation of foetal loss in sheep. J. agric. Sci., Camb. $89,151-152$.

Robinson, J.J., Fraser, C. \& McHattie, I. (1975) The use of progestagens and photoperiodism in improving the reproductive rate of the ewe. Annls Biol. anim. Biochim. Biophys. 15, 345-352.

Scaramuzzi, R.J., Caldwell, B.V. \& Moor, R.M. (1970) Radioimmunoassay of luteinizing hormone and estrogen during the estrous cycle of the ewe. Biol. Reprod. 3, 110-119.

Shevah, Y., Black, W.J.M., Carr, W.R. \& Land, R.B. (1974) The effect of lactation on the resumption of reproductive activity and the preovulatory release of LH in Finn $\times$ Dorset ewes. J. Reprod. Fert. 38, 369378.

Shevah, Y., Black, W.J.M. \& Land, R.B. (1975) The effects of nutrition on the reproductive performance of Finn $\times$ Dorset ewes. J. Reprod. Fert. 45, 289-299.

Siegel, S. (1956) Non-parametric Statistics, pp. 116-127. McGraw-Hill, New York.

Received 20 April 1979 